\title{
EVALUATION OF WILLINGNESS TO PAY FOR IRRIGATION WATER: HARRAN PLAIN SAMPLING IN GAP REGION - TURKEY
}

\author{
AYDOGDU, M. H. ${ }^{1 *}$ \\ ${ }^{1}$ Agricultural Economics Department, Agricultural Faculty, Harran University, Osmanbey \\ Campus, 63200, Sanliurfa, Turkey \\ (phone: +90-414-318-38-62; fax: +90-414-31-37-99) \\ "Corresponding author \\ e-mail:mhaydogdu@hotmail.com,mhaydogdu@harran.edu.tr \\ (Received $21^{\text {st }}$ Sep 2015; accepted $16^{\text {th }}$ Jan 2016)
}

\begin{abstract}
The aim of the paper is to evaluate the willingness to pay (WTP) for irrigation and explore the potential factors that contribute to it. The data used in this study come from a sample of farmers in The Southeastern Anatolian Project (GAP)-Turkey, who were chosen via simple random sampling method and interviewed face to face by given questionnaire. Based on the collected survey data, econometric model for the contingent valuation and double bond maximum likelihood methods were used for analysis by limited dependent package program. Results indicate that farmers are willing to pay $71.69 \%$ more than the existing price under certain conditions, but are paying 98 Turkish Liras/ha less. Accordingly, the yearly annual income loss of the water user associations is $\$ 9,748,011$. Explanatory factors, such as price of irrigation water, education, location, irrigation type (gravity or pumping), and attitudes toward associations, significantly explained WTP. This study is one of the first of its type in Turkey. The study determines the primary factors influencing farmers' WTP for the irrigation water for optimal management of associations and water resources. The results are important for policymakers and contain useful information for Turkey and other countries with similar technical and socio-cultural characteristics.
\end{abstract}

Keywords: irrigation water, willingness to pay, water user association, GAP Region, Turkey

\section{Introduction}

Irrigation water and its management are becoming increasingly important. Water supply cannot meet the demands of the increasing world population; therefore, water has become a strategic element. Population size is the most important factor affecting the future use of water resources and quality, but the effective use, financing and management of water is additionally important. One of the determining factors of water availability will be water users and, their WTP for the financing of systems and the sustainable management of water resources (Aydogdu, 2012). The cost of maintenance, repair and management of the irrigation systems is now being transferred to water users.

The agricultural sector has a significant place in the economy of many countries and uses about $70 \%$ of global water consumption (UNESCO-WWAP, 2003). Water pricing is used as the main tool for regulating irrigated water, which is affected by farmers' income, water supply cost (operation, maintenance and management), political purposes (ensuring food security, social and economic development of some regions), and also water deficiencies. Creating accurate and acceptable prices for an effective and efficient water use is the main purpose of pricing; how to determine these prices is still under discussion till date. Water pricing methods in all countries and even within different regions in countries, are sensitive to physical, social, institutional and political formations. No consensus has been reached regarding the appropriate tools to employ in 
determining the fees and irrigation water pricing, in both developing and developed countries (Koç, 1998).

The price of water may reflect different considerations, such as reducing the amount of water used and saving, demand management, the financing of irrigation institutions, cost recovery and repaying those who have invested in irrigation. Most importantly, the price should not exceed the users' ability to pay. The implementation of an effective water management, a good knowledge of farmers' demand for water is crucial in assessing the reactions to water pricing policy, and to establish a cost-benefit analysis of water supply investments, or to determine the optimal water allocation between different users (Storm et al., 2011). In practice, the most widely pursued objectives, are cost recovery and demand management by water charging in irrigated agriculture (Bosworth et al., 2002).

The Contingent Valuation Method (CVM) is a flexible, non-market valuation method. It has been widely used for more than three decades (Mitchell and Carson, 1989; Tang et al., 2013) for the estimation of the economic value of a resource. Afterwards, the CVM was also being used, in the evaluation of marketable goods. CVM is accepted as an appraisal technique and used in many subject matter, including transportation, sanitation, health, the arts and education, as well as in the environment (Carson, 1994), where the revealed preference models fail due to disequilibrium in the market (Mundy and McLean, 1998), and more details are given in some studies (Portney, 1994; Hanemann, 1994; Carson et al., 2000).

There are many CVM studies on different resources for estimation of the WTP; some of them have been conducted in agricultural irrigation. The farmer's WTP varies significantly with time, and changes due to some factors, such as the price of the product, inputs and education levels in the Phitsanulok irrigation project, in northern Thailand (Tiwari, 1998). The marginal value of water for irrigation is estimated to about $0.06 € / \mathrm{m}^{3}$, which is equivalent to $\$ 67$ for an acre-foot in Chalkidiki, a typical rural area in Greece (Mallios and Latinopoulos, 2001). Farmers accepted to pay 2.5 fold more for secure and sustainable water supply for the purpose of irrigation in Jordan (Salman and Al-Karablieh, 2004). The farmers expressed WTP between $0.21 € / \mathrm{m}^{3}$ and $0.36 € / \mathrm{m}^{3}$ ,and the average was found to be $0.27 € / \mathrm{m}^{3}$ for secure water in summer time, in Granada, Spain and the attitude towards the use of alternative sources (such as residual water) is also examined, (Leyva and Sayadi, 2005). The pricing of irrigation water at adequate levels in Jordan, is seen as a crucial lever to elicit water savings, raise water productivity, ensure financial sustainability, and allocate water economically, for the development of irrigation systems (Venot et al., 2007). Membership satisfaction is an important factor to consider in payment behavior; transparency and trust regarding management, cost recovery rates, farm size and irrigation costs were identified as key determinants for the performance of water communities in the Bregalnica region, in Macedonia (Gorton et al., 2009). The smallholder irrigators show the willingness to pay considerably higher water prices, due to the existence of improvement changes in the water rights system in South Africa (Speelman et al., 2010). The farmers are willing to pay for recycled water for irrigation purposes, especially during drought times in the Thessaly region, Greece (Bakopoulou et al., 2010). The combinations of tools, for the irrigation water demand management and farmers' acceptances were analyzed in the Krishna river basin, India. The results indicated that under the conditions of improved water rights, preference for volumetric pricing increases, whilst the presence of Water User Associations (WUAs) reduces it (Veettil et al., 2011). The elicit farmers are 
willing to increase the current irrigators' community annual payment by $10 \%$ and $20 \%$, moreover, they are willing to reduce the average supply of their administrative water concession by $30 \%$, in order to increase their guarantee for a secured water supply for irrigation in the south of Spain (Mesa-Jurado et al., 2012). The current irrigation water price is too low to achieve the sustainable use of water in the Shiyang River basin; northwest China, based on a study of the farmers' WTP for irrigation water which determines the influencing factors (Tang et al., 2013). The studies showed that WTP is directly affected by the factors of safe water, water rights, trust, transparency, scarcity, education levels and prices.

The agricultural sector has a significant place in the economy of Turkey. The proportion of the Gross Domestic Product (GDP) from agriculture was 8.4\% in the year 2010. It is projected to be $7.8 \%$ for the year 2013 (Mevlana Development Agency, 2013). Developing land and water resources, increasing their contribution to the national economy as a rational operation of irrigation facilities, and ensuring food security as well as the sustainability of the system, are of great importance. In this sense, it is essential to operate irrigation facilities based on the principles of effectiveness and efficiency. This is only possible if there is periodic payment and financing, wherein the most basic determinant is the willingness or the unwillingness to pay for irrigation by users.

The amount of irrigable land is 8.50 million ha in Turkey, due to technical and economic reasons as well as surface and underground water resources (DSI, 2013). At the beginning of the year 2012, 5.61 million ha of this area was irrigated. 82.2\% of land has been irrigated by the state, mainly by the General Directorate of State Hydraulic Works (DSI, in its Turkish acronym) and $17.8 \%$ has been irrigated by the public (farmers), (DSI, 2013). The state, the DSI, is the authority saddled with the responsibility of irrigation investment and management, in Turkey. The state irrigation networks suffer from high cost burdens, inadequate management, repair and maintenance services and the inability to collect the full irrigation fees from the beneficiaries, due to several constraints. These limitations have led the state to search for new irrigation providers. The DSI began to transfer the irrigation works to certain units, led by the WUA, which was created by the union of local management units through an understanding with the "participatory irrigation management". The performance of the WUA with the indicators of utility, productivity, sustainability and financial efficiency was found to be positive; while the performance of adequacy was identified as poor (Uysal and Atış, 2010). DSI largely withdrew from irrigation management and transferred $97 \%$ of its irrigation network (DSI, 2013). Two significant results have been obtained as a result of the transfer. First, the maintenance and repair costs in the state budget were reduced. Second, water fees and collection rates increased (Çakmak, 2010). However, irrigation systems still need structural changes regarding operation, maintenance and management.

Irrigation water is effectively regarded as a non-market goods and does not carry a market price tag in many countries (Tang et al., 2013), including Turkey. Concerning water management policies, prices are a controlling tool (Sahin, 2007). Pricing of water services is underdeveloped, and shows differentiations according to the regions in Turkey (Anonymous, 2013a). Price differentiation may be preferable in certain areas with a lower fee, in this sense; water pricing can be used to eliminate regional disparities, such as in the GAP Region, Turkey. This might be applied as a political choice or the government's preferred social policy. Higher and lower prices will affect 
the level of social welfare and benefits accruing to it. If water fees are kept low in some areas where water resources are insufficient for the whole irrigation area, water may become overused, political preferences will not take place and refunding of the system may encounter problems with financing, such as in the GAP Region. And also, there is a lack of clarity in the objectives of water fee policies in Turkey. Where the objective is to recover some part of the cost of service delivery, the range of costs that may or may not be factored into the price calculation is large. In practice, pricing policies seek only to recover the annual operation and maintenance costs, such as in the GAP Region, and possibly, some fraction of the capital investment costs in Turkey.

Irrigation systems and the services provided by the WUA, and the ability to pay, were evaluated in previous studies in Turkey. The majority of the studies are related to the irrigation systems available in the Harran Plain-GAP, which is the largest irrigation project in Turkey. However, no study has been conducted on the WTP of farmers' for irrigation water. For instance, the water pricing policy in Turkey is expected to cover the entire organization and operating costs (Unver and Gupta, 2003). The current water prices are lower than the costs of water supply in agricultural irrigation in Turkey (Halcrow-Dolsar, 2000; Aydogdu, 2012). The water fee is the main source of revenue of for the WUAs in Turkey. Irrigation water fees have been determined by taking into consideration, the crop area for gravity irrigation, and volume for pump irrigation. Legal changes should be made immediately, in order to achieve sustainable WUAs. Irrigation water pricing is expected to balance multiple objectives, such as economic efficiency, equity, water saving, management effectiveness and financial sustainability (Cakmak et al., 2004). The farmers' WTP for higher quality irrigation water and the determining factors in making payment decisions were analyzed in the Turhal region-Turkey; results showed that the male producer has more WTP (Basarir et al., 2009). Water pricing is the most basic tool in ensuring the sustainability of irrigation systems, and may have positive effects on the drainage problems (Yenigun and Aydogdu, 2010). It cannot be said that conducted water management provides the expected benefits from GAP irrigations under the existing conditions. It has serious problems, such as; Crop pattern in cultivated areas, the given amount of water, salinization due to irrigation and the resulting soil quality and yield losses, lack of training and supervision, elections of WUAs and the collection of water fees (Aydogdu et al., 2014c). Agricultural water pricing cannot be said to be satisfactorily developed in Turkey. The water fee collection time is important for payment. The perceptions and attitudes of farmers towards water fees are sensitive at different levels, in terms of the level of education, age, experience, amount of land and income (Aydogdu et al., 2014d; Aydogdu et al., 2015). The purpose of this study is to determine the amount and the primary factors affecting WTP, which is one of the first for agricultural irrigation in GAP Turkey. The study is based on field observations and an analysis of face to face surveys.

\section{Materials and methods}

\section{Study area}

The GAP is a multi-sectorial, integrated, regional development and complex project. GAP seeks to use the region's resources to increase the income level and quality of life, to eliminate a developing inter-regional inequality, and to contribute to the economic development and social stability targets at the national level. There are 22 dams, 19 hydroelectric power plants and 1,822 million ha of irrigated agricultural land. The total 
investment cost is $\$ 32$ billion (GAP, 2012). Harran Plain is the study field that covers 150,000 ha, at 375 meters of altitude, and is among the lowest altitude locations in the GAP. The average precipitation is between $300 \mathrm{mms}-365 \mathrm{mms}$, and the annual evaporation is 1,848 mms (State Meteorology Works, 2011; Anonymous, 2013b). The WUAs established in the year 1994, have been conducting operations, repairs, maintenance and management activities, under the supervision and inspection of the DSI. However, ever since WUAs became operational, they were unable to provide services at the desired level of productivity due to several reasons, such as; a lack of experience to manage such a big irrigation system, insufficient managers, WUAs' election systems, membership satisfaction and so on.

\section{Materials}

A sample of 21,094 farmers in the Harran Plain, chosen via a simple random sampling method, were used in this study. There are 22 WUAs and 363 settlements in the plain. Sampling was conducted in about $48 \%$ of the settlements in the irrigation season of the year 2011 by questionnaires and face to face interviews. The sample size was determined using the formula of Yamane (2001), with a 95\% confidence interval. The values indicated that conducting 377 questionnaire interview would be appropriate, but to be on the safe side, 471 questionnaire interviews were conducted. Within this scope, all the WAUs in the Plain were visited. To ensure the credibility of the results, villages that represent the WUA were intentionally selected, and local interviewers were used.

\section{Methods}

The CVM, Double Bond Maximum Likelihood Method and Limited Dependent Variable (LDV) models, were used in this study. The CVM involves a survey, directly asking people, how much they would be willing to pay for specific environmental services. It is called contingent valuation, because people are asked to state their WTP, contingent, on a specific hypothetical scenario (Anonymous, 2016). Maximum Likelihood Method (MLM) is responsible for estimating the parameters that maximize the likelihood function of a sample with the feedback values, by means of estimators. The basic principle is the "random occurrence of an event, which is most likely to happen due to that incident." It was invented by Fisher (Stigler, 2007). The LDV models, called the logit model, use the logistic distribution function. In the case of a qualitative dependent variable, yes is classified as 1 and no is 0 in the LDV models (Gujarati, 1995).

Here, irrigation water is a natural resource, and particular theoretical market,which is formed based on questions, were asked for payment requests regarding safe water availability, and a high service quality given by WUAs and the acceptance of payments. If the answers to the questions related to pricing in the survey, are positive, the payment amount is randomly increased toward a predetermined limit value. If the answers are negative, then, there is a reduction in the proposed amount. The value is reduced until the respondent accepts the payment amount or until the WTP amount is reached. Thus, the demands of individuals are determined. This method is contingent because the answer changes according to the initial value. The unit value of natural resources is obtained from a face to face interview, and then, it is multiplied by a population factor. The value function is estimated, and the values of the WTP are calculated at the end. The model summary is given in Figure 1. Lastly, to test the model's accuracy and 
reliability, obtained values are compared with the values predicted by the model, which are commonly used and comes from the nature of the model (Bilgic and Eren, 2008).

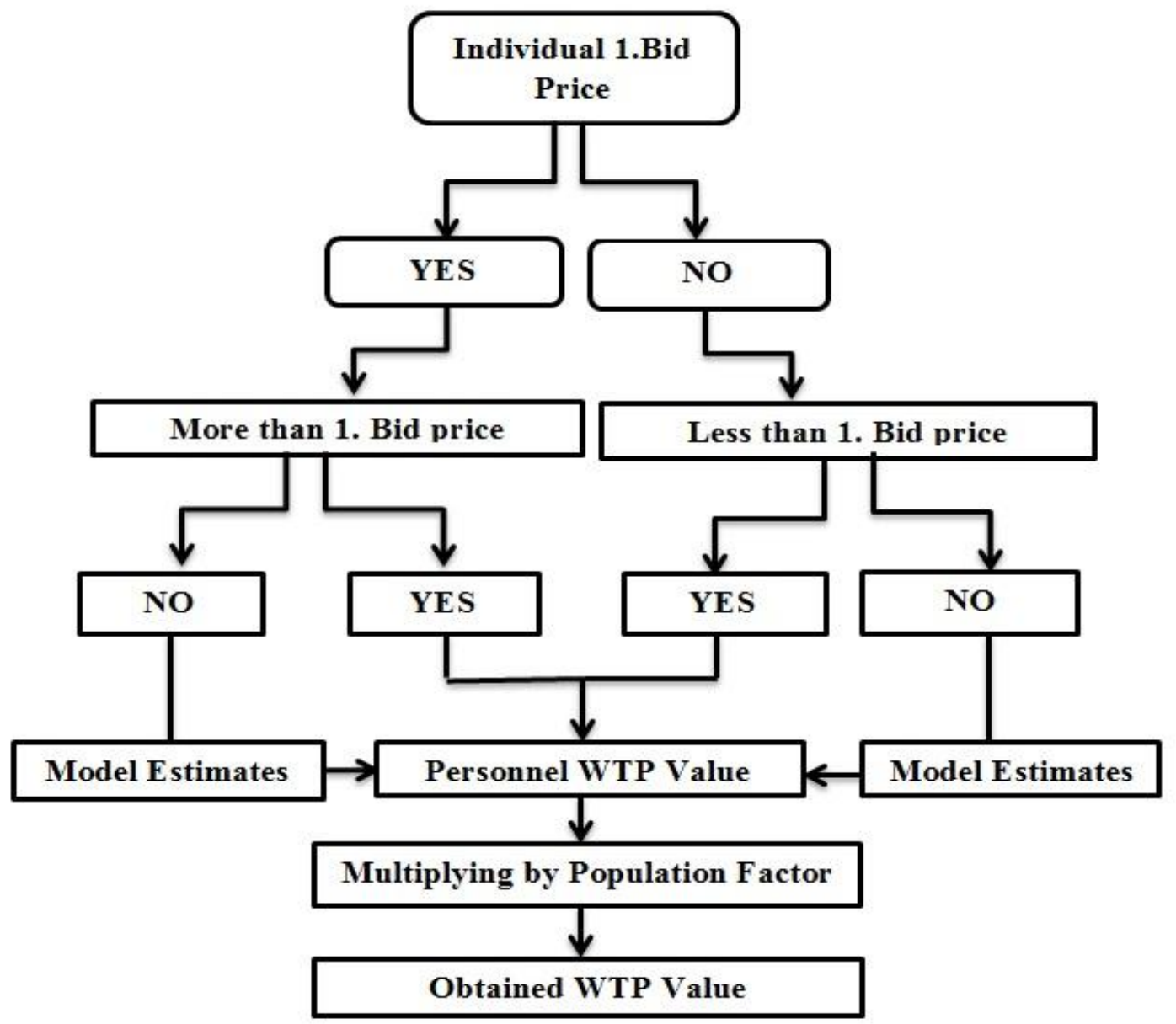

Figure 1. The model summary

A latent benefit index is assumed to be connected with the example of $\mathrm{I}_{\mathrm{i}}$, depending if farmers accept the amount offered. The availability of the two conditions is dependent on an event. This latent benefit index is connected to a set of independent variable, such as $X$. The likelihood of an event increases, if the benefit index has a positive value due to the positive responses given to the offered prices (Gujarati, 1995; 2006; Greene, 2003).

The index $\mathrm{I}_{\mathrm{i}}$ is defined as:

$$
\mathrm{I}_{\mathrm{i}}=\mathrm{X}_{\mathrm{i}} \beta+\varepsilon_{\mathrm{i}}
$$

Each dependent variable has a certain value from $\mathrm{I}_{\mathrm{i}}$ (critical or initial value) of the event, if the respondent says yes to the offered amount. If the value of $I_{i}$ exceeds the amount, the respondent will say yes to the offered amount, if otherwise, the respondent will say no. The initial value is latent because $I_{i}$ is not observed, while assuming a normal distribution with the same mean and variance, dispersed $\beta$ parameters are estimated from the values of $\mathrm{I}_{\mathrm{i}}$. The normal distribution assumption can be calculated 
using a standardized distribution function (Maddala, 1983; Greene, 2003; Gujarati, 2006). The probability values belonging to the parameter set and related to the offered amount, are obtained by taking the natural logarithm of the maximum likelihood function. When the probability approaches zero, the WTP decreases gradually. The opposite happens when it approaches 1 . There is a randomly determined sample with known distribution coefficients of different population candidates in the MLM. In this study, a double bound MLM is used. The method has four possible outcomes. These are (yes, yes), (yes, no), (no, yes) and (no, no). The average WTP can be found after estimating the MLM using the model.

The independent variables are selected according to the economic and the sociocultural structure of the region. The Region has tribal and patriarchal family structure, that is why age is selected and gender is not. The level of education in the region is low, and this affects expectations, attitudes and pricing (Aydogdu, 2012). Almost 50\% of farmers had graduated from primary schools. It is intended to determine significant differences due to the level of education. Marital status (94.5\% married) and household numbers (more than 7) are important in agriculture, because they constitute agricultural labor and power. Location is important in accessing irrigation canals, in order to get enough and safe water, that affects both the irrigation types (gravity, pumping), and the irrigation techniques (modern or furrow irrigation). Land amount, crop type and ownership status affects welfare and income which have a direct effect on WTP. The indexes are explained in the descriptive statistics of the models which may affect the payment behaviors and the WTP of farmers. Lastly, the price of irrigation water has a direct effect on WTP.

The data are transferred to Excel by a coding plan. The econometric model is established, and data analyses are performed using the LIMDEP (Limited Dependent) package program. The effects and WTP are measured, and the statistically significant effects are interpreted.

\section{Results and Discussion}

\section{The survey of the study area}

The total expanse of cultivated land, including the second crop, is 7,660 ha in the surveyed area, and 59\% of the farms are 10 ha or smaller. Of the producers, $59.5 \%$ farm only on their own land, and $40.5 \%$ own their farmland, in addition to other rented lands and/or partnerships. $88.5 \%$ of lands are located in the gravity irrigation area, and $11.5 \%$ are located in the pumping irrigation area. $56.9 \%$ of the farmers are willing to obtain water from an irrigation channel, $7.4 \%$ are willing to obtain water from groundwater wells, and $35.7 \%$ of them from both. Cotton is the main crop being cultivated in the area by $58.1 \%$, followed by wheat $25.6 \%$, corn by $13.6 \%$; other crops by $2.7 \%$. Generally, the wheat and cotton are the first crops to be planted; corn, and rarely cotton, are planted as the second product. Such as wheat and then cotton, or wheat and then, corn, wheat is a winter crop and it is cultivated by irrigation in the plain.

The average income from agricultural activities was calculated as $37326 \mathrm{TL} / \mathrm{year}$ and the average income was $2517.7 \mathrm{TL} / \mathrm{ha}$. The average irrigation water price was 136.7 $\mathrm{TL} / \mathrm{ha}$. Farmers have been paying $5.43 \%$ of their net income per ha for irrigation as a water fee, which is not beyond their ability to pay, but they are generally unwilling to pay to WUAs. In fact, there are many reasons for unwillingness to pay, in terms of farmers' side. Such as; the membership satisfaction, transparency, lack of interest and 
acceptability, except during the election periods, not getting enough water in peak irrigation season, especially in the lower part of the plain and in locations which are far away from the main canal, service quality, lack of adequate information about agricultural activities by the WUAs for increasing agricultural income.

The WUAs are also inefficient in collecting full water fees, such as; election system, which is based on delegate system, every village has representatives from the farmers for elections, depending on land size. The chairmen have concerns about re-election and to be a chairman shows status and power in the region. WUAs have no right under the law to deny farmers of water, regardless of paying water fees or not. They have a right to send notifications to farmers for payment of water fees, and charge them to court if they fail to comply, which takes time and may cause trouble in terms of tribal relationship in the region. And also, the interest rate for delayed payment is not high. There is also a lack of qualified staffs for irrigation activities.

\section{Descriptive statistics of the models}

The descriptive statistics of the model is given in Table 1.

Table 1. The descriptive statistics of the variables used in the model

\begin{tabular}{|c|c|c|c|c|}
\hline \multirow[t]{2}{*}{ VARIABLES } & \multirow{2}{*}{$\begin{array}{l}\text { DEFINITION } \\
\text { (Farmer) }\end{array}$} & \multirow[t]{2}{*}{ VALUE } & \multicolumn{2}{|c|}{ STATISTICS } \\
\hline & & & Mean & $\begin{array}{l}\text { Standard } \\
\text { Deviation }\end{array}$ \\
\hline PRIMARY & If graduated from primary school 1 ; if not 0 & $1 / 0$ & 0.478 & 0.500 \\
\hline SECONDARY & If graduated from secondary school 1 ; if not 0 & $1 / 0$ & 0.166 & 0.372 \\
\hline HIGHSCHOOL & If graduated from high school 1 ; if not 0 & $1 / 0$ & 0.166 & 0.372 \\
\hline UNIVERSITY & If graduated from university 1 ; if not 0 & $1 / 0$ & 0.074 & 0.263 \\
\hline MARRIED & If married 1 ; if not 0 & $1 / 0$ & 0.945 & 0.229 \\
\hline OWNERSHIP & If cultivated land belong to him 1 ; if not 0 & $1 / 0$ & 0.595 & 0.492 \\
\hline HARRAN & If located in Harran district 1 ; if not 0 & $1 / 0$ & 0.348 & 0.478 \\
\hline AKCAKALE & If located in Akcakale district 1 ; if not 0 & $1 / 0$ & 0.253 & 0.435 \\
\hline MDRNIRR & If uses modern irrigation techniques 1 ; if not 0 & $1 / 0$ & 0.178 & 0.383 \\
\hline CROP & If cotton and wheat planting 1 ; if not 0 & $1 / 0$ & 0.412 & 0.493 \\
\hline GRAVITY & If located in gravity irrigation area 1 ; if not 0 & $1 / 0$ & 0.885 & 0.319 \\
\hline PUMPING & If wanted to use pumping irrigation 1 ; if not 0 & $1 / 0$ & 0.074 & 0.263 \\
\hline AGE & Age of the farmer & Year & 43.851 & 10.737 \\
\hline HOUSEHOLD & The number of dependent persons & Person & 7.040 & 3.758 \\
\hline LAND & The amount of cultivated land size & Number & 148.357 & 214.034 \\
\hline INDEXA & $\begin{array}{c}\text { The multiple-question index that measures the } \\
\text { overview to WUAs }\end{array}$ & $\begin{array}{l}\text { Numerical } \\
\text { Value }\end{array}$ & 33.512 & 7.251 \\
\hline INDEXB & $\begin{array}{l}\text { The multiple-question index that measures the } \\
\text { overview to Natural Resources }\end{array}$ & $\begin{array}{l}\text { Numerical } \\
\text { Value }\end{array}$ & 4.355 & 1.628 \\
\hline INDEXC & $\begin{array}{l}\text { The multiple-question index that created in order } \\
\text { to understand the economic value of water }\end{array}$ & $\begin{array}{l}\text { Numerical } \\
\text { Value }\end{array}$ & 9.454 & 1.854 \\
\hline PRICE & $\begin{array}{l}\text { The increase in existing water price by starting } \\
\text { from } 5 \% \text { and multiples up to } 100 \% \text { by randomly }\end{array}$ & Percentage & 47.856 & 20.547 \\
\hline
\end{tabular}


Indexes have been established to measure the perceptions and attitudes of farmers. Indexa comprises a set of ten questions measuring farmers' views towards WUA; satisfaction and knowledge of issues regarding relevant legislations and regulations, values range from 10 , which is the most positive viewpoint, to 50, the most negative perspective. Indexb consists of three questions regarding farmers' knowledge and views towards natural resources, values of the Indexb range from 4 , the most positive viewpoints to natural resources, to 5 , which is the most negative perspective, and 9 indicate no awareness of the issues. Indexc consists of three questions regarding the farmers' understanding about the economic value of water, the values of the Indexc range from 11, which is the most positive, to 7 which is the most negative.

\section{Results of Double Bond Logit Model}

The farmers were asked whether they were willing to pay more than the current water fees for better and safe irrigation with high service quality offered by the WUAs. To find the acceptance percentage by farmers, existing water fees starting from 5\% and multiples, increased up to $100 \%$ per ha, and was randomly drawn for each respondent. Respondents were asked to accept the increased value. If the respondent said no to the first offer, a second offer less than the first one was randomly drawn, and respondents were asked their WTP. If farmers say yes to the first offer, a second one higher than the first offer was randomly drawn and respondents were asked their WTP. The increase in the amount was determined using the double bound MLM, based on the WTP. Before proceeding to a discussion of the results, a comparison carried out between the probability values and the actual values resulting from the model is given in Table 2.

Table 2. The comparison of double bond limited WTP value to the derived estimated value

\begin{tabular}{lcccc}
\hline Model & $\begin{array}{c}\text { Actual Value } \\
\text { (Probability) }\end{array}$ & $\begin{array}{c}\text { Actual Value } \\
\text { (TL) }\end{array}$ & $\begin{array}{c}\text { Estimated Value } \\
\text { (Probability) }\end{array}$ & $\begin{array}{c}\text { Estimated Value } \\
\text { (TL) }\end{array}$ \\
\hline Logit & $0.4295(\%)$ & 23.47 & $0.4789(\%)$ & 24.28 \\
t value & 187.55 & & 168.21 & \\
\hline
\end{tabular}

The difference between the predicted values and the actual values is quite low. The model was estimated having an actual value with an error margin of $4.94 \%$, and a value of $0.81 \mathrm{TL}$. The model succeeded more than expected in terms of outcome prediction. The coefficients and values of the parameters from the logit model are given in Table 3. difference between the predicted values and the actual values is quite low. The model was estimated an actual value with an error margin of $4.94 \%$, a value of $0.81 \mathrm{TL}$. The model succeeded more than expected in terms of outcome prediction. The coefficients and values of the parameters from logit model are given in Table 3.

Table 3. The coefficients and the values of the double bond limited logit model

\begin{tabular}{|c|c|c|c|c|c|}
\hline \multirow{2}{*}{ Variables } & \multirow[t]{2}{*}{ Coefficient } & \multirow[t]{2}{*}{ t-value $(z)$} & \multirow[t]{2}{*}{ p-value } & \multicolumn{2}{|c|}{ 95\% Confidence Level } \\
\hline & & & & Lower Limit & Upper Limit \\
\hline CONSTANT & 1.401 & 1.12 & 0.264 & -1.059 & 3.861 \\
\hline PRIMARY & 0.425 & 1.33 & 0.185 & -0.203 & 1.051 \\
\hline SECONDARY & 0.324 & 0.83 & 0.407 & -0.441 & 1.089 \\
\hline HIGHSCHOOL & 0.236 & 0.61 & 0.545 & -0.528 & 1.000 \\
\hline
\end{tabular}




\begin{tabular}{|c|c|c|c|c|c|}
\hline UNIVERSITY & $0.468^{\mathrm{a}}$ & 1.68 & 0.094 & -0.079 & 1.016 \\
\hline MARRIED & 0.205 & 0.45 & 0.652 & -0.687 & 1.097 \\
\hline OWNERSHIP & -0.210 & -0.98 & 0.326 & -0.628 & 0.208 \\
\hline HARRAN & $1.027^{\mathrm{c}}$ & 4.43 & 0.000 & 0.573 & 1.482 \\
\hline AKCAKALE & $0.661^{b}$ & 2.37 & 0.018 & 0.115 & 1.207 \\
\hline MDRNIRR & 0.210 & 0.87 & 0.387 & -0.266 & 0.687 \\
\hline CROP & 0.009 & 0.04 & 0.967 & -0.434 & 0.453 \\
\hline GRAVITY & $-0.387^{a}$ & -1.68 & 0.092 & -0.838 & 0.633 \\
\hline PUMPING & $0.381^{\mathrm{a}}$ & 1.78 & 0.075 & -0.039 & 0.780 \\
\hline AGE & 0.003 & 0.33 & 0.744 & -0.017 & 0.023 \\
\hline HOUSEHOLD & 0.012 & 0.33 & 0.741 & -0.058 & 0.081 \\
\hline LAND & 0.157 & 1.06 & 0.290 & -0.134 & 0.447 \\
\hline INDEXA & $-0.012^{\mathrm{a}}$ & -1.62 & 0.096 & -0.027 & 0.003 \\
\hline INDEXB & -0.043 & -0.68 & 0.497 & -0.165 & 0.080 \\
\hline INDEXC & 0.016 & 0.33 & 0.744 & -0.079 & 0.111 \\
\hline PRICE & $-5.531^{\mathrm{c}}$ & -17.50 & 0.000 & -6.151 & -4.912 \\
\hline \multicolumn{5}{|c|}{ The logarithmic likelihood function } & 562.124 \\
\hline \multicolumn{5}{|c|}{ Restricted log-likelihood function } & 0.000 \\
\hline \multicolumn{5}{|c|}{ Chi-Square $\left(\chi_{20}^{2}\right)$} & 1124.247 \\
\hline
\end{tabular}

The coefficient of the marginal effects and the values of the double bound logit model are given in Table 4.

Table 4. The marginal effects and the values of the double bond limited logit model

\begin{tabular}{lcccccccc}
\hline Variables & $\begin{array}{l}\text { Probability } \\
\text { (Yes, Yes) }\end{array}$ & \multicolumn{2}{c}{$\begin{array}{c}\text { Probability } \\
\text { (Yes, No) }\end{array}$} & \multicolumn{2}{c}{$\begin{array}{c}\text { Probability } \\
\text { (No, Yes) }\end{array}$} & \multicolumn{2}{c}{$\begin{array}{c}\text { Probability } \\
\text { (No, No) }\end{array}$} \\
\hline & coefficient & $\begin{array}{c}\mathbf{t} \\
\text { value }\end{array}$ & coefficient & $\begin{array}{c}\mathbf{t} \\
\text { value }\end{array}$ & coefficient & $\begin{array}{c}\mathbf{t} \\
\text { value }\end{array}$ & coefficient & $\begin{array}{c}\mathbf{t} \\
\text { value }\end{array}$ \\
\hline PRIMARY & 0.0008 & 1.28 & 0.0015 & 1.28 & 0.0044 & 1.28 & -0.0067 & -1.28 \\
SECONDARY & 0.0005 & 0.91 & 0.0010 & 0.91 & 0.0031 & 0.91 & -0.0046 & -0.91 \\
HIGHSCHOOL & 0.0004 & 0.65 & 0.0008 & 0.65 & 0.0023 & 0.65 & -0.0035 & -0.65 \\
UNIVERSITY & $\mathbf{0 . 0 0 0 9}$ & $\mathbf{1 . 7 4}$ & $\mathbf{0 . 0 0 1 8 ^ { \mathbf { a } }}$ & $\mathbf{1 . 7 3}$ & $\mathbf{0 . 0 0 5 3}$ & $\mathbf{1 . 7 3}$ & $\mathbf{0 . 0 0 8 0 ^ { \mathbf { a } }}$ & $\mathbf{1 . 7 3}$ \\
MARRIED & 0.0004 & 0.41 & 0.0008 & 0.41 & 0.0023 & 0.41 & -0.0035 & -0.41 \\
OWNERSHIP & -0.0004 & -0.97 & -0.0007 & -0.97 & -0.0022 & -0.97 & 0.0033 & 0.97
\end{tabular}




\begin{tabular}{|c|c|c|c|c|c|c|c|c|}
\hline HARRAN & $0.0017^{\mathrm{c}}$ & 3.89 & $0.0032^{c}$ & 3.91 & $0.0096^{\mathrm{c}}$ & 3.96 & $0.0145^{\mathfrak{c}}$ & 3.94 \\
\hline AKCAKALE & $0.0010^{c}$ & 2.48 & $0.0020^{c}$ & 2.48 & $0.0060^{c}$ & 2.49 & $0.0091^{\mathrm{c}}$ & 2.49 \\
\hline MDRNIRR & 0.0004 & 0.91 & 0.0007 & 0.91 & 0.0021 & 0.91 & -0.0031 & -0.91 \\
\hline CROP & 0.0000 & 0.04 & 0.0000 & 0.04 & 0.0001 & 0.04 & -0.0002 & -0.04 \\
\hline GRAVITY & $0.0001^{b}$ & -1.98 & $-0.0008^{b}$ & -2.11 & $-0.0046^{b}$ & -2.16 & $0.0055^{b}$ & 2.15 \\
\hline PUMPING & 0.0007 & 1.62 & 0.0014 & 1.62 & 0.0041 & 1.63 & -0.0062 & -1.62 \\
\hline AGE & -0.0001 & -0.33 & -0.0001 & -0.33 & -0.0001 & -0.33 & 0.0001 & 0.33 \\
\hline HOUSEHOLD & -0.0001 & -0.33 & -0.0001 & -0.33 & -0.0001 & -0.33 & 0.0002 & 0.33 \\
\hline LAND & -0.0003 & -1.07 & -0.0006 & -1.07 & -0.0016 & -1.07 & 0.0025 & 1.07 \\
\hline INDEXA & 0.0001 & 1.25 & 0.0001 & 1.25 & 0.0002 & 1.25 & -0.0003 & -1.25 \\
\hline INDEXB & 0.0001 & 0.68 & 0.0002 & 0.68 & 0.0004 & 0.68 & -0.0007 & -0.68 \\
\hline INDEXC & -0.0001 & -0.33 & -0.0001 & -0.33 & -0.0002 & -0.33 & 0.0003 & 0.33 \\
\hline PRICE & $0.0101^{\mathrm{c}}$ & 7.25 & $0.0195^{\mathrm{c}}$ & 7.36 & $0.0577^{\mathrm{c}}$ & 7.65 & $-0.0873^{c}$ & -7.53 \\
\hline
\end{tabular}

There is a relationship between WTP and level of education. It is statistically significant for university graduates $(\mathrm{p} \leq 0.10)$ which is an expected result. Because, when the level of education increases, the awareness about irrigation also increases. There is a negative relationship that exists between the WTP and gravity irrigation users. They are located in bigger irrigation areas $(88.5 \%)$ and use more water. Therefore, an increased water fee implies more expenses and adversely affects their prosperity. It is statistically significant $(\mathrm{p} \leq 0.10)$.

There is a relationship that exists between the WTP and residing in Harran. The Imambakir WUA is located in the lowest altitude of the plain. The groundwater level is high and intensive salinity is observed in these areas due to excessive irrigation. The Imambakir WUA has an area of 7,464 ha of land, and the groundwater level has been affected, leading to salinity problems and significant yield losses (Aydogdu et al., 2014a). Besides, a resident within the boundaries of Harran, living towards the end of the main canal and close to the Akcakale, stated that they could not obtain sufficient water for their needs during peak period. So, they made use of underground water and wells. Any increase in water fees will reduce water usage in the upstream and bring about a positive effect on the downstream WUAs, in terms of decreased salinity and increased water amounts to use. It is statistically significant $(\mathrm{p} \leq 0.01)$.

There is a relationship between WTP and Akcakale located towards the end of the main irrigation canals. The farmers stated that they could not obtain sufficient water for their needs during the peak season. Irrigation is also conducted via pumping, in order to 
meet their water needs in Akcakale. Increased fees will reduce water usage in the upstream and result to increase in the amount of water available for the downstream. Hence, more costly pumping irrigation will decrease and bring about a positive impact on the welfare of farmers. Moreover, a price increase will positively affect WTP due to salinization. Salinity has led to a $1,840,625 \mathrm{~kg}$ yield loss of cotton in the year 2009; the resulting income loss was $\$ 935,711$ in Akcakale (Aydogdu et al., 2014b). This result is statistically significant $(\mathrm{p} \leq 0.05)$.

There is a relationship between WTP and gravity irrigation users. When farmers cannot obtain enough amount of water from the canal, they either reduce the planted areas or obtain water from the groundwater wells which is 2.6 fold expensive, for their field. Under both conditions, farmers are bound to experience some welfare losses. This result is statistically significant $(p \leq 0.10)$. There is a relationship that exists between price increase and the WTP. The multiplicity of relationships between variables is correspondingly negative. The price increase affects the WTP negatively, such that when one increases, the other decreases. Vice versa is also applicable. This result is expected and is statistically significant $(\mathrm{p} \leq 0.01)$.

The statistically significant variables' marginal effects have been analyzed based on maximum likelihood of WTP and they are used in a double bond limited model. Among the respondents who said yes to both scenarios, the education reference category of University graduates affected the WTP more, compared to the other education layers, but the impact of education on WTP is limited in terms of their numerical value. Alternatively, Akçakale and Harran farmers have an increased likelihood of payment. There is an observed difference in the payment likelihood of farmers who prefer the gravity irrigation system, relative to those who do not prefer this system. When the price offer increases, it results in decreases in farmers' WTP as well as a decrease in the likelihood of payment. The reverse is also true: the lower bid price will increase farmers' WTP and likelihood of payment.

According to the results of the model, farmers who are University graduates have a higher WTP as compared to the reference group, for those who say yes to the first offer and no to the second increased offer. Akçakale and Harran farmers have an increased likelihood of payment relative to the ones in other regions. Gravity irrigation user farmers have lower WTP and a reduced probability of WTP, as compared to pumping irrigation user farmers. Here, a higher price offered has a negative effect on the WTP, as expected.

Based on the results of the model; farmers who are university graduates have higher WTP among those who say no to the first offer and yes to the second increased offer, as compared to the reference group. Akçakale and Harran farmers increase the likelihood of payment. The decrease in the offered price increases the WTP, as expected. In this farmers group, those obtaining gravity irrigations have lower WTP and a reduced probability of WTP, as compared to pumping irrigation user farmers.

From the results of the model; farmers who graduated from the university have higher WTP among those who say no to both scenarios in the reference group. Akçakale and Harran farmers show an increased likelihood of payment compared to farmers in other regions. The decrease in the price offered has a positive effect on their WTP. Gravity irrigation user farmers have higher WTP and an increased probability of WTP compared to pumping irrigation users. 


\section{The Education scenario applied to model for the determination of the change in WTP}

The relationship between farmers' WTP and education level was examined. Education is the most important subject in terms of economic, social and cultural development in the region. Positive increments of education level for six different proportions, that indicate the next upper level of education, $10 \%, 25 \%, 40 \%, 50 \%, 75 \%$ and $100 \%$ were tested. Changes were observed in the WTP of farmers. Increase in farmers' education will result to an increased WTP of farmers. The results are shown in Figure 2.

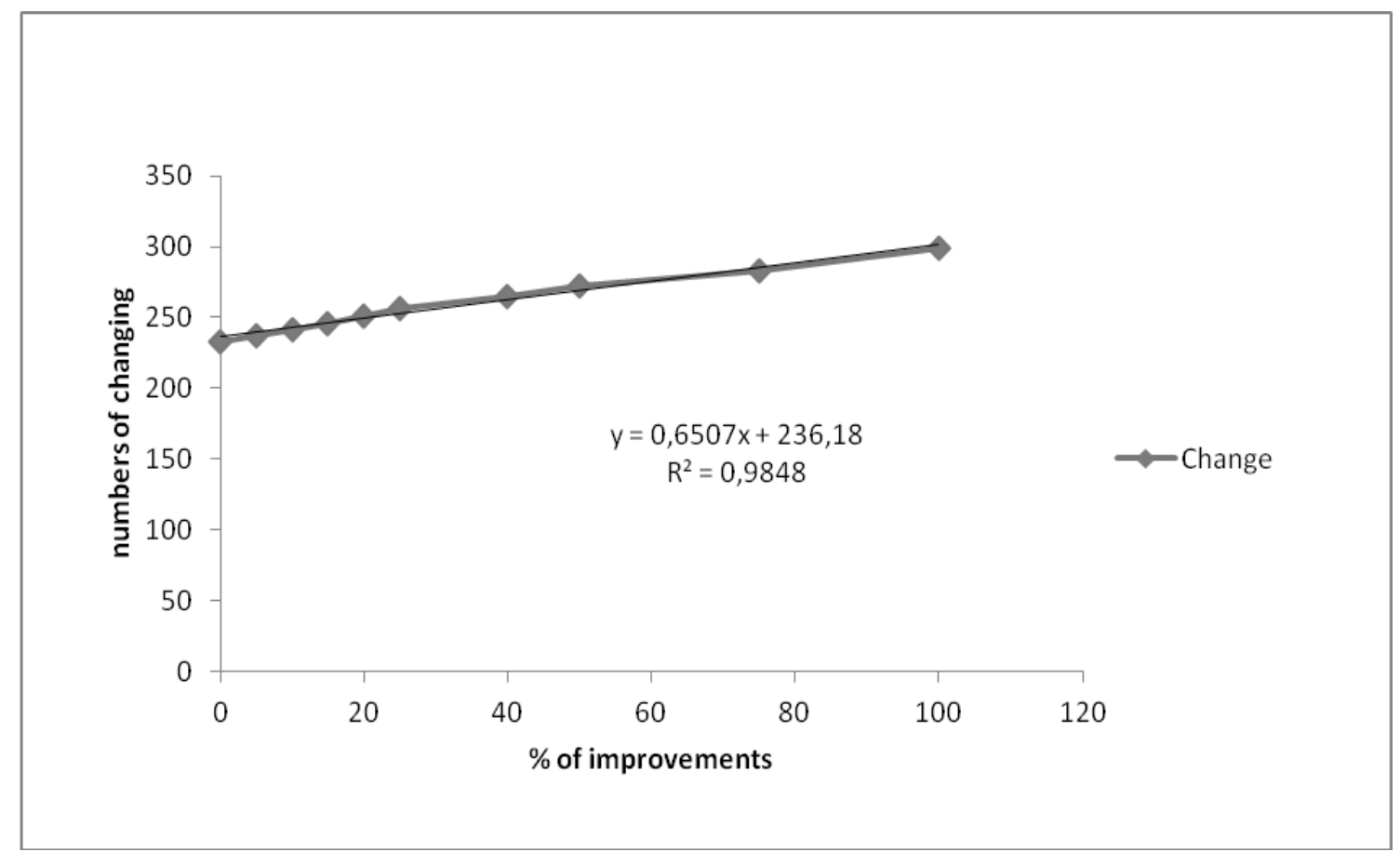

Figure 2. The change in WTP depending on improvements applied to the education variable

\section{Conclusions}

Water fee mainly covers the operation, maintenance and management costs in the Harran Plain. In order to ensure the sustainability of the irrigation systems, water fees should be paid. The dominant factor is farmers' attitude to payment. This research determined the factors affecting (and factors also not affecting) farmers' payment and the WTP.

The factors of age, household numbers, ownership, crop pattern, land, indexb and indexc were expected to be statistically significant, but they were not. These results arise from the peculiar conditions of the region, as follow: the region is semi-arid, regardless of age level, everyone knows the meaning and economic value of water. There is an increase in income level due to irrigation, without depending to on the crop type, land amount and ownership status. Household members are also considered as a labor force outside agriculture. The most unexpected result was Indexb, which is about natural resources (mainly water and soil), and their availability for future use. It is believed that natural resources are sufficient to meet the future needs. This result arose from a lack of awareness about natural resources, mainly come from individuals with 
lower education levels, but also from the perceptions of the future, which is time based, that is, for the next couple of years. And also perceptions about the source of irrigation water. Atatürk dam, which is the main source of irrigations, is the $6^{\text {th }}$ largest dam in the world, in terms of embankment volume, together with $817 \mathrm{~km}^{2}$ of lake area, 48.7 billion $\mathrm{m}^{3}$ of water storage capacity, and the average yearly flow rate is 26.7 billion $\mathrm{m}^{3}$ (DSİ, 2013). It is believed that Atatürk dam will also meet the future needs.

The results show that the average WTP is $234.7 \mathrm{Tl} /$ ha which is substantially higher than the existing average water price, which was $136.7 \mathrm{Tl} /$ ha. In other words, farmers' WTP is more than $71.69 \%$ of the existing price, and paying $98 \mathrm{Tl} / \mathrm{ha}$ less. Explanatory factors, such as the price level, education, settlement area, irrigation type (gravity or pumping), farmers' attitudes toward the WUAs (membership satisfaction, trainings, service quality) included in the model, were statistically significant.

This study reveals that farmers are charged a much lower water fee than their WTP in a region where all of the irrigation structures and a majority of costs are subsidized by the state. It is impossible to meet up with the operation, maintenance, repair and management costs of the system mainly and continuously with government finances. Ensuring the sustainability of the irrigation system is possible in terms of social, economic, and balancing environmental and social targets provided all the relevant parties work together. Basic economics require that the price of a service should be, at least, as high as the cost of providing that service, which indicates that the sustainable and efficient use of water, requires the tariff to at least, match the costs of supply (Tang et al., 2013). Farmers are the main user and are responsible for payment of the system. An insufficient budget would cause insufficient infrastructure and water services, and farmers, in turn, will become less willing to pay for the poor quality services provided by the WUAs and vice versa.

Currently, the expenditure complexity of GAP prevents us from obtaining the accurate supply costs of irrigation water in the plain. However, the cost of water is much lower than the actual cost of supply in Turkey. When the fees stray from the reflection of the real scarcity value of water, water may be used carelessly, and as a result, causes drainage problems. The low water fee causes unsustainable usage, and the cost recovery appears to be caused mainly by a lack of WTP, rather than by an inability to pay. Currently, the Harran plain irrigation area is approximately 150,000 ha. The difference between the current price and the WTP is $98 \mathrm{Tl} / \mathrm{ha}$, thus, leading to 14.7 million TL/year, as a lost revenue for the overall plain, which is based on the year 2010 irrigation fees. (The average value of $1 \$=1.508 \mathrm{TL}$ and $1 €=1.999 \mathrm{TL}$, Anonymous, 2013c). Accordingly, the yearly annual income loss of the WUAs in the Harran Plain was $\$ 9,748,011$.

WTP may depend largely on the ability to pay (Perry et al., 1997), and is positively related to income. Usually, the ability to pay or affordability is measured in terms of the water fee being a reasonable proportion of income. The survey results showed that the farmers in the plain were paying an average of 5.43\%, of their net income from agriculture as water fees; WTP average is $10.73 \%$ of their net income. Increased price will reduce farmers' net income, though, they have the capacity to pay. In addition, without irrigation, meaningful production cannot exist in this semi-arid area. There are already problems in collecting water fees. Farmers are unwilling to pay, and the WUAs are not adequately successful in collecting water fees. If transparency, participation, information, training and awareness are provided by the WUAs, the farmers would have WTP more than current fees. Farmer satisfaction increases the WTP. The reverse is also true. 
As a result, if information and trainings are given in the appropriate places in an understandable manner as regards the affecting factors, the WTP of the farmers will increase. This increase will result in the adoption of measures to improve water efficiency and contribute to the financing of the system in a sustainable way. So, agricultural water management will become more efficient and can be implemented in a proper manner. As an outcome, the farmers' welfare will increase as well as that of the society. The results which serve as a guide to the WUAs and decision makers in irrigation and water policies, can be designed realistically for the sustainable management of the irrigation networks. The results are also important in the formation of irrigation policies, and contain useful information for Turkey and other countries with similar technical and socio-cultural characteristics.

\section{REFERENCES}

[1] Anonymous. (2013a): Decision of The Council of Ministers about water pricing tariffs for 2104, Decision number 2013/5626.

[2] Anonymous. (2013b): web:http://www2.dsi.gov.tr/bolge/dsi15/isletme.htm, 12 Dec 2013.

[3] Anonymous. (2013c): web:http://www.isyatirim.com.tr/p_exchange_avarege.aspx,05Aug 2013.

[4] Anonymous. (2016): http://www.ecosystemvaluation.org/contingent_valuation.htm, 05 Jan 2016.

[5] Aydogdu, M., Aydogdu, M.H., Cullu, M.A. (2014a):The Impact Determination On Cotton Yields Of Soils Which Have Different Salt Levels And Its Relation With Satellite Data (Şanlıurfa İmambakır Harran Plain Irrigation Association). - Turkish Studies 9(2): 231-250. Doi: 0.7827/ TurkishStudies.6009

[6] Aydogdu, M., Aydogdu, M.H., Cullu, M.A. (2014b): The Determination of The Cotton Productivity And Losses Under The Effect Of Salinity By GIS And Remote Sensing, (GAP Region, Akçakale Sampling) Turkey. - The Journal of Academic Social Science Studies 24:617-630. Doi:http://dx.doi.org/10.9761/JASSS2167.

[7] Aydogdu, M.H. (2012): Agricultural Water Management And Pricing In Sanliurfa-Harran Plain, Problems And Solutions, Ph.D. Thesis, Harran University, Sanliurfa, Turkey.

[8] Aydogdu, M.H., Karlı, B., Yenigün, K., Manc1, A.R., Aydogdu, M. (2014c): The Structural Problems Of Water User Associations And Recommended Solutions In The Harran Plain In GAP Region, Turkey. - International Journal of Social Science 28:179196. Doi:http://dx.doi.org/10.9761/JASSS2488.

[9] Aydogdu, M.H., Karlı, B., Yenigün, K., Manc1, A.R., Aydogdu, M. (2014d): Pricing Trends In Agricultural Irrigation; Attitudes And Perceptions Of Farmers To Pricing; GAP-Harran Plain Irrigations, Şanliurfa. - International Journal of Social Science 29:165-188. Doi:http://dx.doi.org/10.9761/JASSS2529.

[10] Aydogdu, M.H., Yenigun, K., Aydogdu, M. (2015): Factors Affecting Farmers' Satisfaction from Water User Associations in the Harran Plain-GAP Region, Turkey Journal of Agricultural Science and Technology. 17(Supplementary issue):1669-1684.

[11] Bakopoulou, S., Polyzos, S., Kungolos, A. (2010): Investigation of farmers' willingness to pay for using recycled water for irrigation in Thessaly region, Greece. - Desalination 250:329-334.

[12] Basarir, A., Sayili, M., Muhammad, S. (2009): Analyzing Producers' Willingness to Pay for High Quality Irrigation Water. - Bulgarian Journal of Agricultural Science 15(6):566573.

[13] Bilgiç, A., Eren, G. (2008): GAP Bölgesinde Kaliteli İçme Suyunun Fiyatlandırılmasına Etki Eden Faktörler, MSc Thesis, Harran University, Sanliurfa, Turkey. (in Turkish) 
[14] Bosworth, B., Cornish, G., Perry, C., Van Steenbergen, F. (2002): Water Charging in Irrigated Agriculture, Lessons from the literature Report OD 145. HR Wallingford Ltd, Wallingford, UK

[15] Cakmak, B., Beyribey, M., Kodal, S. (2004): Irrigation water pricing in water user associations, Turkey. - International Journal of Water Resources Development 20(1):113-124.

[16] Çakmak, E. (2010): Agricultural Water Pricing: Turkey, OECD Study, pp.5-27.

[17] Carson, R.T. (1994): A Bibliography of Contingent Valuation Studies and Papers. Natural Resource Damage Assessment, Inc., La Jolla, California.

[18] Carson, R.T., Flores, N.E., Meade N.F. (2000): Contingent Valuation: Controversies and Evidence Environmental and Resource Economics. http://econweb.ucsd.edu/ rcarson/ cvconfinal.pdf

[19] DSİ. (2013): Tarım ve Sulama, DSİ Genel Müdürlüğü, Ankara. (in Turkish)

[20] GAP. (2012): GAP Administration, GAP'ta Son Durum, p.6. Sanliurfa. (in Turkish)

[21] Gorton, M., Sauer, J., Peshevski, M., Bosev, D., Shekerinov, D.,Quarrie, S. (2009): Water Communities in the Republic of Macedonia: An Empirical Analysis of Membership Satisfaction and Payment Behavior. - World Development 37(12):1951-1963.

[22] Greene, W.H. (2003): Econometric Analysis. Prentice Hall, 1050p., New Jersey.

[23] Gujarati, D.G. (1995): Basic Econometrics. Mc Graw-Hill Int Edit., 705p., NY, USA.

[24] Gujarati, D.G. (2006): Temel Ekonometri, (Translation: Şenesen U., and Şenesen G.G.) Literatur Publication, Istanbul. (in Turkish)

[25] Halcrow-Dolsar JV. (2000): İşletme, Bakım ve Onarım Projesi, Taslak Sonuç Raporu, Şanliurfa. (in Turkish)

[26] Hanemann, W.M. (1994): Valuing the Environment Through Contingent Valuation. The Journal of Economic Perspectives 8(4):19-43

[27] Koç, C. (1998): Büyük Menderes Havzası Sulama Şebekelerinde Organizasyon-Yönetim Sorunları ve Araştırmalar, İzmir. (in Turkish)

[28] Leyva, J.C., Sayadi, S.(2005): Economic valuation of water and willingness to pay analysis with repect to tropical fruit production in southeastern Spain. - Spanish Journal of Agricultural Research 3(1):25-33

[29] Maddala, G.S. (1983): Limited Dependent and Qualitative Variables in Econometrics. Cambridge, 356 p., London.

[30] Mallios, Z., Latinopoulos, P. (2001): Willingness to pay for irrigation water: a case study in Chalkidiki, Greece. - In: Lekkas, T. D. (ed.) Proceedings 7th International Conference on Environmental Science and Technology, Ermoupolis, Greece

[31] Mesa-Jurado, M.A., Martin-Ortega, J., Rutoc, E., Berbeld, J. (2012): The economic value of guaranteed water supply for irrigation under scarcity conditions. - Agricultural Water Management 113:10-18

[32] Mevlana Development Agency . (2013): TR52 Düzey 2 Bölgesi, 2023 Vizyon Raporu, Tarım Sektör Raporu, Konya. (in Turkish)

[33] Mitchell, R.C., Carson, R.T. (1989): Using Surveys to Value Public Goods: The Contingent Valuation Method. Johns Hopkins University Press, Baltimore, MD.

[34] Mundy, B., McLean, D. (1998): The Addition of Contingent Valuation and Conjoint Analysis to the Required Body of Knowledge for the Estimation of Environmental Damage to Real Estate. - The Journal of Real Estate Practice and Education. http://www.greenfieldadvisors.com/publications/contingentvaluation.pdf

[35] Perry C.J., Rock M., Seckler D. (1997): Water as an economic good: A solution, or a problem?, Research Report 14. International Irrigation Management Institute, Colombo, Sri Lanka.

[36] Portney, P.R. (1994): The Contingent Valuation Debate: Why Economists Should Care. - The Journal of Economic Perspectives 8(4):3-17 
[37] Şahin, A. (2007): Türkiye'de Tarımsal Su Kullanımında Fiyatlama Politikaları, Kamu-İş̧ 9:3 Ankara. (in Turkish)

[38] Salman, A.Z., Al-Karablieh, E. (2004): Measuring the willingness of farmers to pay for groundwater in the highland areas of Jordan. - Agricultural Water Management 68:61-76.

[39] Speelman, S., Farolfi, S., Frija, A., D'haese, M.,D'haese, L. (2010): The impact of the water rights system on smallholder irrigators' willingness to pay for water in Limpopo province, South Africa. - Environment and Development Economics 15:465-483

[40] State Meteorology Works. (2011): http://www.dmi.gov.tr/veridegerlendirme/il-veilceleristatistik.aspx? $\mathrm{m}=$ Sanliurfa $(16$ Nov 2011) (in Turkish)

[41] Stigler, S. M. (2007): The Epic Story of Maximum Likelihood. - Statistical Science 22(4): 598-620, Doi: 10.1214/07-STS249.

[42] Storm, H., Heckelei, T., Heidecke, C. (2011): Estimating irrigation water demand in the Moroccan Drâa Valley using contingent valuation. - Journal of Environmental Management 92:2803-2809.

[43] Tang, Z., Nan, Z., Liu, J. (2013): The willingness to pay for irrigation water: A case study in Northwest China. - Global Nest Journal 15(1):76-84.

[44] Tiwari D.N. (1998): Determining Economic Value of Irrigation Water, CSERGE Working Paper GEC, 98-05.

[45] UNESCO-WWAP. (2003): Water for People, Water for Life, The United Nations World Water Development Report, http://www.unesco.org/water/wwap/wwdr/ex_summary/ ex_summary_en.pdf

[46] Unver, O., Gupta, R. (2003): Water Pricing: Issues and Options in Turkey. - Water Resources Development 19(2):311-330.

[47] Uysal Ö.K., Atış E. (2010): Assessing the performance of participatory irrigation management over time: A case study from Turkey. - Agricultural Water Management, 97(7):1017-1025.

[48] Veettil, P.C., Speelman, S., Frija, A., Buysse, J., Huylenbroeck, G.V. (2011): Complementarity between water pricing, water rights and local water governance: A Bayesian analysis of choice behaviour of farmers in the Krishna river basin, India. Ecological Economics 70:1756-1766.

[49] Venot, J. P., Molle F., Hassan, Y. (2007): Irrigated Agriculture, Water Pricing and Water Savings in the Lower Jordan River Basin (in Jordan) Comprehensive Assessment of Water Management in Agriculture Research Report 18.

[50] Yamane, T. (2001): (Translation: Esin, A., Bakır, M.A., Aydın, C., Gürbüzsel, E.) Temel Örnekleme Yöntemleri, Literatur Publication, Istanbul. (in Turkish)

[51] Yenigun, K., Aydogdu, M.H. (2010): Evaluation of Irrigation and Drainage Systems of GAP, the Turkey's Largest Integrated Water Resource Development Project. - Scientific Research and Essays 5(21):3237-3253. 